\title{
Comparative efficacy of the conventional and automated methods for determining neutral and acid detergent fiber
}

\author{
Éder Cristian Malta de Lanes'*, Fernando César Ferraz Lopes², Núbia Ribeiro Campos², \\ Jackson Silva e Oliveira², Mirton José Frota Morenz², Roberto Frische-Neto' \\ ' Federal University of Viçosa, Viçosa, MG, Brazil \\ 2Brazilian Agricultural Research Corporation Dairy Cattle, Coronel Pacheco, MG, Brazi \\ *Corresponding author, e-mail: edercml@gmail.com
}

\begin{abstract}
Different methods are available to determine fiber content in feeds. However, information about the accuracy of this methods for neutral detergent fiber (NDF) and acid detergent fiber ADF contents estimation (obtained with the use of TNT-100 nylon filtering bags) is very limited related to the large number of ruminant feed analysis. The purpose of this study was to compare the efficacy of the automated and conventional Van Soest methods to determine NDF and ADF contents for bovine cattle and feed supplements. Four classes of samples (tropical forage, maize silage hybrid, concentrated supplements and bovine cattlecattle) were evaluated for NDF and ADF contents using conventional and automated methods. Analysis involved a hierarchical factorial scheme with an entirely randomized design executed with repetitions. It was concluded that the automated method procedure generated similar results when compared to the conventional method for the determination of NDF contents in tropical forage, bovine cattle and maize silage samples, although is not recommended for samples with a high starch content. This system was not efficient for ADF determination in the evaluated samples.
\end{abstract}

Keywords: maize silage, fiber analysis, forage

\section{Eficácia comparativa dos métodos convencional e automatizado na determinação das fibras em detergente neutro e ácido}

\section{Resumo}

Existem vários métodos para a determinação da concentração de fibra em alimentos. Entretanto, poucas são as informações disponíveis a respeito da acurácia nas estimativas dos teores de fibra em detergente neutro (FDN) e fibra em detergente ácido (FDA), obtidos por meio da utilização do equipamento automatizado empregando-se a utilização de saquinho de filtragem TNT-100, para a grande maioria dos alimentos fornecidos na dieta dos ruminantes. Este trabalho teve como objetivo comparar a eficácia dos métodos automatizado e convencional utilizados na determinação da FDN e FDA em amostras de alimentos e fezes de bovino. Para a determinação da FDN e FDA, quatro classes de amostras (forrageiras tropicais, silagens de híbridos de milho, suplementos concentrados e fezes de bovinos) foram avaliadas usando-se o método convencional e automatizado. Os dados foram analisados utilizando o esquema hierárquico fatorial em delineamento inteiramente casualizado, com três repetições. Concluiu-se que o procedimento método automatizado apresentou resultados semelhantes aos do método convencional para a determinação da concentração de FDN em forragem tropical, fezes de bovino e em amostras de silagem de milho, mas não é recomendado para as amostras com elevado teor de amido. Este sistema não foi eficiente para a determinação da FDA em qualquer uma das amostras utilizadas.

Palavras-chave: análise de fibra, forragem, silagem de milho 


\section{Introduction}

Van Soest's (1963, 1967) methodology that uses detergents for fibrous feeds analysis consists of quantitative analysis of plant cell wall constituents (Möller, 2009). These constituents can be separated by using two detergents: neutral detergent fiber (NDF) and acid detergent fiber (ADF). Over the years this method, which has practical limitations as the time, human and financial resources demands and laboratory infrastructure (Berchielli et al., 2001), has undergone several modifications (Mertens, 2002).

In order to increase the efficiency of the quantification process, instruments have been developed in order to automate fiber analysis systems. The Filter Bag Technique (FBT) by Ankom ${ }^{\circledR}$ is a practical example of this and has been used to the analysis of many types of feeds with different characteristics and origins (Marichal et al., 2011), and also aims the reduction of the variability associated with the operator Komarek (1993).

The TE-149 is another apparatus available on the market (TECNAL ${ }^{\circledR}$ - Laboratory Equipment, Piracicaba, SP, Brazil) for fiber analysis that involves the digestion and filtration of feed samples using nylon bags in a closed environment. This technique ensures homogeneous conditions of digestion and filtration for all samples and allows a greater number of tests per day, since the washing and filtering steps, which are usually executed manually, are automated (Berchielli et al., 2001; Kitcherside et al., 2000). However, information on the accuracy of this device's NDF and ADF content estimates (obtained in conjunction with TNT-100 nylon filtering bags) is very limited since the vast number of of ruminant feed. This approach must be validated on a wide variety of forages before becoming generally accepted. Although previous researches compared both methodologies (Berchielli et al., 2001; Bortolassi et al., 2000; Fay et al., 2009), they do not include most of the feeds of interest in animal nutrition research.

Thus, this work aimed to compare the efficacy of the automated and conventional methods for determining neutral detergent fiber (NDF) and acid detergent fiber (ADF) content in feed samples and bovine cattle.

\section{Materials and Methods}

Samples

The study was carried out at the Laboratory of Feed Analysis of the Embrapa Dairy Cattle Unit, Juiz de Fora, MG. Two systems used for determining NDF and ADF content were compared: 1) the conventional method; 2) an automated method, using a forage fiber analyzer model TE-149. The study involved four classes of samples (tropical forage, maize silage hybrids, concentrated supplements and bovine cattle) routinely used in ruminant nutrition tests.

The nine species of tropical forage used were: 85 Tifton-grass (Cynodon dactylon (L.) Pers); African star-grass (Cynodon nlemfuensis, Vanderyst); Brachiaria humidicola (Rendle); Brachiaria ruziziensis (Germani and Everard); Tanzania-grass and Mombasa-grass (Panicum maximum, Jacq). The three sugarcane cultivars (Saccharum officinarum, L.) were CB-47-355, RB-73-9735 and SP-79-2233. Samples of grass and sugarcane were obtained after 70 and 301 days of growth, respectively, after trimming for uniformity and the subsequent chemical fertilization (300 kg ha-1 of the 10-06-10 formula). The samples were cutted approximately $5 \mathrm{~cm}$ from ground level, crushed with an stationary crusher and pre-dried in an oven with forced ventilation $\left(60 \pm 5{ }^{\circ} \mathrm{C} ; 72 \mathrm{~h}\right)$ for the determination of partial dry matter (Silva and Queiroz, 2002). Afterwards, the pre-dried samples were ground in a Wiley mill (Thomas Scientific, Swedesboro, NJ, USA) with a screen porosity of $1 \mathrm{~mm}$.

Fecal samples were collected from confined cows (Holstein $x$ Zebu) that received a diet based on maize silage supplemented with concentrated feed or from cows grazing in elephant-grass (Pennisetum purpureum, Schum.) or brachiaria-grass (Brachiaria brizantha, cv. Marandu) pastures, supplemented or not with concentrates and bulk (sugarcane + urea; maize silage).

The maize silage samples (Zea mays I.) were collected in the municipality of Lages-SC. These maize were cut, ensiled and approximately 30 days after closing, the silos were opened to determine chemical-bromatological composition. The hybrids used were: SHS4070, AG5011, GARRA, ATTACK, BRS3003, SG4018, 
DKB566, DKB21 4 and AG8021.

The following concentrated supplements were sampled and evaluated: sesame bran, soybean bran, cassava scraps, maize meal, citrus pulp, damp maize silage, barley, cotton seeds, cotton bran, crushed soy beans and wheat bran.

Analytical methods

To determine NDF and ADF with the conventional method, $0.3 \mathrm{~g}$ of the sample was weighed and placed in test tubes, to which 30 $\mathrm{mL}$ of neutral or acid detergent solution were added. To determine the NDF of samples with high starch content, $0.2 \mathrm{~mL}$ of thermo-stable $\square$-amylase and $9.0 \mathrm{~mL}$ of urea were added per tube. Subsequently, these tubes were sealed with aluminum seals and autoclaved at $120^{\circ} \mathrm{C}$ for $60 \mathrm{~min}$. These samples were later filtered in previously-weighed filtering crucibles (porosity between 40 and $100 \mu$ - i.e., number 2). The samples in the crucibles were washed with hot distilled water and acetone and incubated at $105^{\circ} \mathrm{C}$ for 8 hours. The NDF and ADF contents were obtained using the method described by Silva and Queiroz (2002).

To determine the NDF and ADF content with the automated system, $0.5 \mathrm{~g}$ of each sample was placed in a previously-weighed TNT-100 (nonwoven fabric material, $100 \%$ polypropylene; 5.5 $x 5.5 \mathrm{~cm}$, porosity of $100 \mu$ ) nylon bag that were subsequently heat sealed with an electric sealer. To determine the NDF content of samples with high starch content, samples were pre-incubated in $0.2 \mathrm{~mL}$ of thermo-stable $\square$-amylase solution and $9 \mathrm{~mL}$ of urea at $90^{\circ} \mathrm{C}$ for $5 \mathrm{~min}$ and maintained in this solution during 24 hours. A volume of $2,700 \mathrm{~mL}$ of neutral or acid detergent solution was added to the fiber analyzer that runned an analysis of 30 nylon bags with nine samples of each class of feed (incubated in triplicates), plus a control sample (standard) and two blanks. For this process, the only exception was the feed concentrate class. Since this class included eleven samples, a new battery of samples was setted up, with a control (standard) and two blanks. Samples contained in the TNT nylon bags were submitted to reflux in detergent solution in an enclosed environment at a temperature of $98.2^{\circ} \mathrm{C}$ (corresponding to 100 ${ }^{\circ} \mathrm{C}$ due to the altitude of the laboratory) under agitation for approximately 80 minutes. After the reflux, the bags were submitted to five washes with hot distilled water for five minutes and then drained and immersed in acetone for five minutes. These nylon-bagged samples were dried in an incubator ( $105^{\circ} \mathrm{C}$; $8 \mathrm{~h}$ ) $\square$ and then placed in a desiccator and weighed after reaching room temperature. The data thus obtained was used to calculate the percentage of ADF according to the following Eq. (1):

$$
\text { \%NDF and/or } A D F=\frac{[P 3-(P 1 \times C 1)] \times 100}{P 2}
$$

Being: $\mathrm{P} 1$ the tare of the nylon bag, P2 the sample weight, P3 the weight after the extraction process and $\mathrm{Cl}$ the correction for the nylon bag blank (final weight of the bag after drying . original bag weight ${ }^{-1}$ ).

\section{Statistical analysis}

To complete this study, a hierarchical factorial scheme $(2 \times 4)$ with an entirely randomized design was executed in triplicates. The data were subjected to analysis of variance considering the following model, where all the effects were considered as fixed: $Y_{i j \mathrm{kl}}=\mu+C_{i}+M_{j}$ $+A_{k} / C_{i}+C M_{i j}+M A_{j k} / C_{i}+e_{i j k l}$ where $Y_{i j k l}=$ is the fiber content observed in class $i$, in sample $k$, by the method $\mathrm{j}$ in repetition $\mathrm{l} ; \mu=$ is the overall average; $C_{i}$ is the effect of samples class $i(i=1,2,3) ; M_{i}$ is the effect of method $j(j=1,2) ; A_{k} / C_{i}$ is the effect of sample $\mathrm{k}$ within the class $\mathrm{i}$; $C \mathrm{M}_{\mathrm{ij}}$ is the effect of the interaction of class $i$ with method $j ; \mathrm{MA}_{\mathrm{j} k} / \mathrm{C}_{i}$ is the effect of the interaction of sample $k$ within the class $i$ with method $j ; e_{i j k l}$ is the experimental error associated with the observation $Y_{\mathrm{ijk} l}$. The data were tested for normality using the KolmogorovSmirnov test. The averages of the treatments were compared using the Tukey test at $5 \%$ of probability level. All analyses were performed using the SAS statistical software v.9.1.

\section{Results and Discussion}

Through analysis of variance it was observed that there was difference ( $p=0.01$ ) between methods, as well as among feed classes and samples within each class. The coefficients of variation (CV) for the NDF and ADF components were 5.14 and $5.47 \%$ respectively, demonstrating a high level of repeatability and precision of the analyses. The coefficient of determination 
$\left(R^{2}\right)$ was 0.99 for both fiber fractions, indicating a good fit of the statistical model to the data observed (Table 1).

Table 1. Average content of neutral detergent fiber (NDF) and acid detergent fiber (ADF) of the sample classes as determined by automated and conventional methods.

\begin{tabular}{|c|c|c|c|c|}
\hline \multirow{2}{*}{ Classes of Feed } & \multicolumn{2}{|l|}{ NDF (\%) } & \multicolumn{2}{|l|}{ ADF (\%) } \\
\hline & Conventional & Automated & Conventional & Automated \\
\hline Tropical Forage & $70.96^{\mathrm{Aa}^{*}}$ & $71.29 \mathrm{Aa}$ & $33.68^{\mathrm{Bb}}$ & $42.43^{\mathrm{Ab}}$ \\
\hline Bovine Cattle & $66.97 \mathrm{Ab}$ & $66.78^{A b}$ & $38.05^{\mathrm{Ba}}$ & $44.96 \mathrm{Aa}$ \\
\hline Maize Silage & $43.14^{\mathrm{BC}}$ & $49.84 \mathrm{AC}$ & $20.43^{B C}$ & $28.90 \mathrm{AC}$ \\
\hline Concentrated Supplements & $23.20 \mathrm{Bd}$ & $39.23 \mathrm{Ad}$ & $12.19 \mathrm{Bd}$ & $21.74 \mathrm{Ad}$ \\
\hline \multirow{2}{*}{ Source } & \multicolumn{2}{|l|}{ NDF (\%) } & \multicolumn{2}{|l|}{$\operatorname{ADF}(\%)$} \\
\hline & \multicolumn{2}{|l|}{$\operatorname{Pr}>\mathrm{F}$} & \multicolumn{2}{|l|}{$\operatorname{Pr}>\mathrm{F}$} \\
\hline Classes & \multicolumn{2}{|l|}{0.0001} & \multicolumn{2}{|l|}{0.0001} \\
\hline Methods & \multicolumn{2}{|l|}{0.0001} & \multicolumn{2}{|l|}{0.0001} \\
\hline Methods*Classes & \multicolumn{2}{|l|}{0.0001} & \multicolumn{2}{|l|}{0.0002} \\
\hline CV\% & \multicolumn{2}{|l|}{5,14} & \multicolumn{2}{|l|}{5,47} \\
\hline$R^{2}$ & \multicolumn{2}{|l|}{0.99} & \multicolumn{2}{|l|}{0.99} \\
\hline
\end{tabular}

\section{Determination of NDF content}

No effect was observed (p>0.05) between the methods used for determining NDF in tropical forage and bovine cattle classes, indicating the efficacy of the automated method for determining the NDF in these materials. However, for the maize silage and concentrated supplement classes, an analytical procedure effect $(P<0.01)$ was observed for NDF content determination (Table 1).

The mean NDF content obtained for the Brachiaria humidicola, Tanzania and Tifton 85 samples was similar in both methods of analysis (Table 2) and also similar to those reported by Valadares Filho et al. (2001). The NDF averages obtained for the sugarcane samples in the "class of tropical forage" did not differed.

Table 2. Averages of the neutral detergent fiber (NDF) and acid detergent fiber (ADF) dry matter (DM) contents of tropical forage samples analyzed by conventional and automated methods.

\begin{tabular}{|c|c|c|c|c|}
\hline \multirow{2}{*}{ Evaluated Samples } & \multicolumn{2}{|l|}{$\%$ DM NDF } & \multicolumn{2}{|l|}{$\%$ DM ADF } \\
\hline & Conventional & TECNAL & Conventional & TECNAL \\
\hline \multicolumn{5}{|l|}{ Tropical Forage } \\
\hline Sugarcane SP-79-2233 & $61.25 \mathrm{~A} \mathrm{C}^{*}$ & $64.01 \mathrm{~A} \mathrm{~cd}$ & $28.32 \mathrm{~B} \mathrm{e}$ & $36.93 \mathrm{~A}$ ef \\
\hline Sugarcane CB-47-355 & $57.32 \mathrm{~A} \mathrm{C}$ & $59.62 \mathrm{~A} \mathrm{~d}$ & $26.94 \mathrm{~B} \mathrm{e}$ & $35.61 \mathrm{~A} \mathrm{f}$ \\
\hline Sugarcane RB-73-9735 & $66.52 \mathrm{~A} \mathrm{bc}$ & $66.12 \mathrm{~A} \mathrm{bcd}$ & $30.81 \mathrm{~B}$ de & $39.09 \mathrm{~A}$ def \\
\hline Brachiaria humidicola & $75.67 \mathrm{~A} \mathrm{ab}$ & $77.39 \mathrm{~A} \mathrm{a}$ & $37.51 \mathrm{~B}$ abc & $46.34 \mathrm{~A} \mathrm{bc}$ \\
\hline Brachiaria ruziziensis & $66.57 \mathrm{~A} \mathrm{bc}$ & $69.80 \mathrm{~A} \mathrm{abc}$ & $29.38 \mathrm{~B}$ de & $37.94 \mathrm{~A}$ ef \\
\hline Cynodon dactylon cv. Tifton 85 & $78.98 \mathrm{~A} \mathrm{a}$ & $78.75 \mathrm{~A} \mathrm{a}$ & $34.12 \mathrm{~B} \mathrm{~cd}$ & $42.61 \mathrm{Acd}$ \\
\hline C.nlemfuensis cv. African Star & $77.59 \mathrm{~A} \mathrm{a}$ & $74.95 \mathrm{~A} \mathrm{ab}$ & $34.37 \mathrm{~B} \mathrm{bcd}$ & $41.79 \mathrm{~A}$ de \\
\hline Panicum maximum cv. Tanzania & $79.22 \mathrm{~A} \mathrm{a}$ & $78.83 \mathrm{~A} \mathrm{a}$ & $41.70 \mathrm{~B} \mathrm{a}$ & $51.54 \mathrm{~A} \mathrm{a}$ \\
\hline P.maximum cv. Mombasa & $75.51 \mathrm{~A} \mathrm{ab}$ & $72.16 \mathrm{~A} a b c$ & $40.02 \mathrm{~B} \mathrm{ab}$ & $50.02 \mathrm{~A} \mathrm{ab}$ \\
\hline
\end{tabular}

Although the NDF determination method had an effect on the maize silage class, the results were consistent with those observed by Berchielli et al. (2001) and Fay et al. (2005). The same was not observed for the intraclass samples, in which both methods showed similar values for maize silage hybrids, with the exception of the GARRA hybrid. A tendency toward automated method NDF value overestimation in the samples of this class was also observed (Table 1 and 3). Similar results were also reported by Ferreira and Mertens (2007). A possible explanation for the high automated method NDF levels in samples of concentrated supplements could be changes in the structure of the nylon bags (TNT-100) that lead to pore obstruction (Bortolassi et al., 2000). However, in some cases the opposite may occur, i.e., dilatation of the bag mesh, which could lead 
to NDF residue losses.

The class of "concentrated supplements" presented similar behavior compared to the "maize silage" class, in which the automated system NDF value was greater than that obtained using the conventional system (Table
1). All samples in this class tended to have overestimated NDF values when analyzed by the automated system but no differences were observed between soy bran, cassava scrap and citrus pulp samples when compared with the conventional method (Table 4).

Table 3. Averages of the neutral detergent fiber (NDF) and acid detergent (ADF) content of maize silage hybrids samples analyzed by conventional and TECNAL automated methods.

\begin{tabular}{|c|c|c|c|c|}
\hline \multirow{2}{*}{ Evaluated Samples } & \multicolumn{2}{|c|}{ NDF of dry matter (\%) } & \multicolumn{2}{|c|}{ ADF of dry matter (\%) } \\
\hline & Conventional & Automated & Conventional & Automated \\
\hline \multicolumn{5}{|l|}{ Hybrid Maize Silage } \\
\hline$A G 8021$ & $35.36 \mathrm{~A} \mathrm{C}^{*}$ & $41.94 \mathrm{~A} \mathrm{~b}$ & $15.05 \mathrm{~B} \mathrm{~b}$ & $22.13 \mathrm{~A} \mathrm{e}$ \\
\hline DKB214 & $37.13 \mathrm{~A} \mathrm{bc}$ & $42.25 \mathrm{~A} \mathrm{~b}$ & $15.67 \mathrm{~B} \mathrm{~b}$ & $23.97 \mathrm{~A}$ cde \\
\hline CLAW & $46.38 \mathrm{~B} \mathrm{ab}$ & $56.12 \mathrm{~A} \mathrm{a}$ & $23.78 \mathrm{~B} \mathrm{a}$ & $34.17 \mathrm{~A} \mathrm{a}$ \\
\hline DKB566 & 35.89 A C & $41.82 \mathrm{~A} \mathrm{~b}$ & $15.19 \mathrm{~B} \mathrm{~b}$ & $23.51 \mathrm{~A}$ de \\
\hline SHS4070 & $49.18 \mathrm{~A} \mathrm{a}$ & $54.73 \mathrm{~A} \mathrm{a}$ & $23.50 \mathrm{~B} \mathrm{a}$ & 33.31 A ab \\
\hline BRS3003 & $46.95 \mathrm{~A} \mathrm{a}$ & $54.01 \mathrm{~A} \mathrm{a}$ & $21.79 \mathrm{~B} \mathrm{a}$ & $31.17 \mathrm{~A}$ ab \\
\hline ATTACK & $44.62 \mathrm{~A}$ abc & $51.05 \mathrm{~A} \mathrm{ab}$ & $20.61 \mathrm{~B} \mathrm{ab}$ & $29.03 \mathrm{~A} \mathrm{abcd}$ \\
\hline AG5011 & $49.31 \mathrm{~A} \mathrm{a}$ & $57.54 \mathrm{~A} \mathrm{a}$ & $24.72 \mathrm{~B} \mathrm{a}$ & $34.78 \mathrm{~A} \mathrm{a}$ \\
\hline SG4018 & $43.41 \mathrm{~A} \mathrm{abc}$ & $49.11 \mathrm{~A} \mathrm{ab}$ & $23.56 \mathrm{~A} \mathrm{a}$ & $28.01 \mathrm{~A} \mathrm{bcd}$ \\
\hline
\end{tabular}

Table 4. Averages of the neutral detergent fiber (NDF) and acid detergent (ADF) contents for concentrated supplement samples analyzed by conventional and TECNAL automated methods.

\begin{tabular}{|c|c|c|c|c|}
\hline \multirow{2}{*}{ Evaluated Samples } & \multicolumn{2}{|c|}{ NDF of dry matter (\%) } & \multicolumn{2}{|c|}{ ADF of dry matter (\%) } \\
\hline & Conventional & Automated & Conventional & Automated \\
\hline \multicolumn{5}{|c|}{ Concentrated Supplements } \\
\hline Sesame bran & $26.55 \mathrm{~B} \mathrm{bc}^{*}$ & $40.88 \mathrm{~A} \mathrm{C}$ & 8.39 B de & 14.46 Af \\
\hline Soy bran & $24.30 \mathrm{~A} \mathrm{bcd}$ & $33.69 \mathrm{~A} \mathrm{~cd}$ & $14.14 \mathrm{~B} \mathrm{Cd}$ & 25.78 A de \\
\hline Cassava scraps & $22.88 \mathrm{~A} \mathrm{~cd}$ & $29.94 \mathrm{~A} \mathrm{~d}$ & $16.33 \mathrm{~B} \mathrm{bc}$ & $21.77 \mathrm{Ae}$ \\
\hline Maizemeal & $15.63 \mathrm{~B}$ de & $36.39 \mathrm{~A} \mathrm{~cd}$ & 2.67 B ef & $7.67 \mathrm{~A} \mathrm{~g}$ \\
\hline Citrus Pulp & $23.27 \mathrm{~A} \mathrm{bcd}$ & $30.36 \mathrm{~A} \mathrm{~d}$ & $19.41 \mathrm{~B} \mathrm{abc}$ & $32.21 \mathrm{~A} \mathrm{~b}$ \\
\hline Damp maize silage & $4.37 \quad B f$ & $14.15 \mathrm{~A} \mathrm{e}$ & 1.70 Af & $2.89 \mathrm{Ah}$ \\
\hline Barley & $40.25 \mathrm{~B} \mathrm{a}$ & $64.35 \mathrm{~A} \mathrm{a}$ & $20.62 \mathrm{~B} \mathrm{ab}$ & $26.91 \mathrm{Acd}$ \\
\hline Cotton seeds & $43.75 \mathrm{~B} \mathrm{a}$ & $68.34 \mathrm{~A} \mathrm{a}$ & $16.67 \mathrm{~B} \mathrm{bc}$ & $28.70 \mathrm{~A} \mathrm{bcd}$ \\
\hline Cotton bran & $33.63 \mathrm{~B} \mathrm{ab}$ & $53.10 \mathrm{~A} \mathrm{~b}$ & $23.08 \mathrm{~B} \mathrm{a}$ & $30.56 \mathrm{~A} \mathrm{bc}$ \\
\hline Soy beans & $11.41 \mathrm{~B}$ ef & $27.22 \mathrm{~A} \mathrm{~d}$ & 3.92 B ef & $38.49 \mathrm{~A} \mathrm{a}$ \\
\hline Wheat bran & 20.12 B cde & $33.15 \mathrm{~A} \mathrm{~cd}$ & 7.12 A ef & $9.75 \mathrm{~A} \mathrm{fg}$ \\
\hline
\end{tabular}

Among the concentrated supplements feeds, with the exception of citrus pulp, the average NDF values observed in this study for both procedures (automated and conventional) disagreed with those reported in the literature (Zambom et al., 2001; Bortolassi et al., 2000). The elevated starch content present in the samples belonging to the "maize silage" and supplements classes may be responsible for the higher NDF values obtained when the automated system was used; gelatinized starch could clog the mesh of the nylon bag during the reflux process, leading to NDF content overestimation (Ferreira and Mertens, 2007). Such differences could be attributed to the action of $\square$-amylase used for feeds with high starch content. According to Carvalho et al. (2006), thermostable amylase presents optimal activity when $\mathrm{pH}$ and temperature are carefully adjusted. Van Soest et al. (1991) comment that $\square$-amylase is rapidly inactivated at a temperature of $100^{\circ} \mathrm{C}$ and that the $\alpha$ 1-6 activity is destroyed by EDTA (component of the neutral detergent solution).

\section{Determination of ADF content}

There were differences between the analyzed methods ( $P<0.05)$ for ADF contnet determination (Table 1), the automated system 
was superior to the conventional procedure for all studied classes of feed and bovine cattle.

There were differences in tropical forage ADF values between the two methods (Table 2). As for the sugarcane samples, although a difference between the methods of analysis was observed, the ADF content did not differ $(P>0.05)$ between cultivars within each analytical procedure. The average ADF values for sugarcane obtained when the automated system were used agree with those reported by Berchielli et al. (2001).

The results for ADF content (Table 5), in seven of the nine bovine cattle samples, differed
$(P<0.05)$ between the two methods used. In fact, there were different results between samples within the automated system. This variation was also observed by Berchielli et al. (2001), who suggested that the interaction between the samples's granulometry and the porosity of the mesh in the bags should be assessed as a way to achieve more conclusive results. Thus, such variations may help to explain the overestimated automated system values compared to the conventional procedure for this type of material. Nevertheless, both treatments were within the range reported by Lopes (2002).

Table 5. Averages for neutral detergent fiber (NDF) and acid detergent fiber (ADF) dry matter (DM) contents of bovine cattle samples analyzed by conventional and TECNAL automated methods.

\begin{tabular}{|c|c|c|c|c|}
\hline \multirow{2}{*}{ Evaluated Samples } & \multicolumn{2}{|l|}{$\%$ DM NDF } & \multicolumn{2}{|l|}{$\%$ DM ADF } \\
\hline & Conventional & TECNAL & Conventional & TECNAL \\
\hline \multicolumn{5}{|l|}{ Bovine Cattle ${ }^{\prime}$} \\
\hline 1 & $67.31 \mathrm{~A} \mathrm{abc}$ & $67.49 \mathrm{~A} \mathrm{a}$ & $35.27 \mathrm{~B} \mathrm{Cd}$ & $45.03 \mathrm{~A} \mathrm{abc}$ \\
\hline 2 & $67.64 \mathrm{~A} a b c$ & $66.93 \mathrm{~A} \mathrm{a}$ & $35.32 \mathrm{~B} \mathrm{~cd}$ & $41.94 \mathrm{~A} \mathrm{Cd}$ \\
\hline 3 & $67.21 \mathrm{~A} \mathrm{abc}$ & $67.18 \mathrm{~A} \mathrm{a}$ & $38.16 \mathrm{~A} \mathrm{bc}$ & 43.59 A bcd \\
\hline 4 & $68.96 \mathrm{~A} \mathrm{ab}$ & $63.36 \mathrm{~A} \mathrm{a}$ & 40.46 B bc & 46.59 A abc \\
\hline 5 & $70.64 \mathrm{~A} a b$ & $68.12 \mathrm{~A} \mathrm{a}$ & $41.16 \mathrm{~B} \mathrm{~b}$ & $48.72 \mathrm{~A} \mathrm{ab}$ \\
\hline 6 & $72.71 \mathrm{~A} \mathrm{a}$ & $71.54 \mathrm{~A} \mathrm{a}$ & 47.09 A a & $49.44 \mathrm{~A} \mathrm{a}$ \\
\hline 7 & $67.46 \mathrm{~A} \mathrm{abc}$ & $69.39 \mathrm{~A} \mathrm{a}$ & $39.06 \mathrm{~B} \mathrm{bc}$ & 46.32 A abc \\
\hline 8 & $58.23 \mathrm{~A} \mathrm{C}$ & $62.55 \mathrm{~A} \mathrm{a}$ & $30.49 \mathrm{~B} \mathrm{~d}$ & $38.47 \mathrm{~A} \mathrm{~d}$ \\
\hline 9 & $62.53 \mathrm{~A} \mathrm{bc}$ & $64.50 \mathrm{~A} \mathrm{a}$ & $35.45 \mathrm{~B} \mathrm{bcd}$ & $44.58 \mathrm{~A} \mathrm{abc}$ \\
\hline \multicolumn{5}{|c|}{$\begin{array}{l}\text { *Averages followed by the same uppercase letters in the rows and lowercase letters in the columns did not differ by Tukey's test (P }>0.05) \text {. }{ }^{1}(1) \text { Bovine cattle of } \\
\text { Holstein } \times \text { Zebu that recceived a diet based on maize silage, concentrated supplement and Brachiaria pasture; (2) Bovine cattle Holstein } \times \text { Zebu that received } \\
\text { a diet based on sugarcane and urea, concentrated supplement and elephant grass pasture; (3) Bovine cattle Holstein } \times \text { Zebu that received a diet based } \\
\text { on concentrated supplement and maize silage; (4) Bovine cattle Holstein } \times \text { Zebu that received a diet based on concentrated supplement and Brachiaria } \\
\text { pasture; (5) Bovine cattle Holstein } \times \text { Zebu receiving a diet based on concentrated supplement and elephant grass pasture; (6) Bovine cattle Holstein } \times \text { Zebu } \\
\text { that received a diet based on concentrated supplement and maize silage; (7) Holstein bovine cattle that receiveda diet based on concentrated supplement } \\
\text { and Brachiaria pasture; (8) Holstein bovine cattle that received a diet based on elephant grass pasture; (9) Holstein bovine cattle that received a diet based } \\
\text { on concentrated supplement and maize silage }\end{array}$} \\
\hline
\end{tabular}

Among the maize silage hybrids (Table 3), differences $(P<0.05)$ between the analysis systems were observed in eight of the maize silage hybrids. However, the average ADF value determined by the automated system for this class agreed with the value determined by the reflectance spectrometry method of a nearinfrared spectroscopy (NIRS) (Fontaneli et al., 2002) as well as with the results of Berchielli et al. (2001), Santos et al. (2003), and Fay et al. (2005 and 2009).

There were differences $(p<0.05)$ between the ADF values obtained for by product feeds (Table 1), with very discrepant results and overestimated values for the automated system. The ADF content (Table 4) of wheat bran and soy bran obtained by the automated and conventional systems were consistent with those in the literature (Bortolassi et al., 2000; Zambom et al., 2001; Santos et al., 2003). Cotton seed and cotton bran samples analyzed by the automated system presented average ADF contents (Table 4) very close to those reported by Bernardes et al. (2007), Oliveira et al. (2008), Santos et al. (2003) and Moreira et al. (2003).

The average ADF values determined by the automated system for citrus pulp and soy bean were much higher than those observed by the conventional method. However, in the automated method, the ADF values were higher than the NDF values for both feeds, which in theory is impossible, since the NDF fraction contain theADF fraction. According to Interlaboratory Quality Control (ANFAR-National Association of Manufacturers of Animal Feed, MAMinistries of Agriculture and Supplies and CATI), the variation in citrus pulp ADF content is due to the analytical procedure adopted. Carvalho 
et al. (2006) reported that the high contents of pectin contained in citrus pulp elevate the ADF values in relation to the NDF values when the sequential procedure described by Van Soest (1967) is not adopted, i.e., when the NDF and ADF are determined in the same sample - which differs from the protocol reported in this study. Therefore, for feeds with high pectin content, the sequential procedure is recommended, due to the fact that pectin is soluble in neutral detergent but less soluble (retained) in acid detergent and can "contaminate" the ADF fraction, resulting in overestimated values for other methods. However, in the present study this behavior was not observed in the conventional procedure, even without the application of the sequential method. According to Cassida et al. (2007), pectin content represented a third of the ADF difference between the fiber analysis methods (non-sequential and sequential).

The observed class and sample differences in ADF content determined by the two analytical procedures (conventional and automated) could be attributed to greater interference during analysis with the conventional method. Examples of this would include starch gelatinization in the pores of filtering crucibles and inefficient removal of sample residues from the interior walls of the test tubes during rinsing procedures. The greatest barrier related to the automated system is clogging in the nylon bag mesh (Bortolassi et al., 2000) due to starch gelatinization or, as previously reported, due to the high contents of pectin present in certain feeds. Furthermore, other factors may influencethe analysis, such as the amount of sample in the TNT-100 bags, the reagents used and finally, deficiencies inherent to the equipment.

\section{Conclusions}

It was concluded that results when the automated method was usedwere similar to those of the conventional method when the NDF contents was determined in tropical forage, bovine cattle and maize silage samples, but is not recommended for samples with high starch content. This system was not efficient for ADF determination in any of the samples used.

\section{Acknowledgments}

We thank the Centre for Higher Education in Juiz de Fora (CES-JF) for funding this study and Embrapa Dairy Cattle Unit for providing the reagents, filter bags and the laboratory infrastructure.

\section{References}

Berchielli, T.T., Sader, A.P.O., Tonani, F.L., Paziani, S.F., Andrade, P. 2001. Avaliação da fibra em detergente neutro e da fibra em detergente ácido pelo sistema ANKOM. Revista Brasileira de Zootecnia 30: 1572-1578.

Bernardes, E.B., Coelho, S.G., Carvalho, A.U. 2007. Efeito da substituição do feno de Tifton 85 pelo caroço de algodão como fonte de fibra na dieta de bezerros. Arquivo Brasileiro de Medicina Veterinária e Zootecnia 59: 955-964.

Bortolassi, J.R., Santos, G.T., Alcalde, C.R., Gonçalves, G.D., Zambom, M.A., Furlan, A.C. 2000. Comparação dos métodos convencional e filter bag technique da Ankom ${ }^{\circledR}$ (FBT) para determinação de fibra em detergente neutro e fibra em detergente ácido. Acta Scientiarum. Animal Sciencies 22: 807-811.

Carvalho, G.G.P., Fernandes, F.E.P., Pires, J.V.P. 2006. Métodos de Determinação dos teores de amido e pectina em alimentos para animais. Revista Electrónica de Veterinaria 7: 1-12.

Cassida, K.A., Turner, K.E., Foster, J.G., Hesterman, O.B. 2007. Comparison of detergent fiber analysis methods for forages high in pectin. Animal Feed Science and Technology 135: 283-295.

Ferreira, G., Mertens, D.R. 2007. Measuring detergent fibre and insoluble protein in silage using crucibles or filter bags. Animal Feed Science and Technology 133: 335-340.

Fontaneli, R.S., Durr, J.W., Scheffer-Basso, S.M., Haubert, F., Bortolini, F. 2002. Validação do Método da Reflectância no Infravermelho Proximal para Análise de Silagem de Milho. Revista Brasileira de Zootecnia 31: 594-598.

Fay, J.P., Guaita, M.S., Danelón, J.L., Chifflet, S., Wawrzkiewicz, M., Fernández, H. M., Ross, D.A. 2005. Evaluation of Two Procedures to Determine Acid and Neutral Detergent Fibers in Ruminant Feeds of the Temperate Region of Argentina. Journal AOAC Internationa 88: 995-997.

Fay, J.P., Guaita, M.S., Danelón, J. L., Chifflet, S., Wawrzkiewicz, M., Díaz, C., Ross, D. A., Fernández, H.M. 2009. Variability Among Four Laboratories of the Filter Bag Technique to Determine Acid and Neutral Detergent Fiber Contents in Ruminant Feeds from Argentina. Journal AOAC 
International 92: 371-374.

Kitcherside, M.A., Glen, E.F., Webster, A.J.F. 2000. FibreCap: an improved method for the rapid analysis of fibre in feeding stuffs. Animal Feed Science and Technology 86: 125-132.

Komarek, A.R. 1993. An improved filtering technique for the analysis of neutral detergent fiber and acid detergent fiber utilizing the filter bag technique. ANKOM Technical Corp., Fairport, USA. 10 p. (Publication No. 101)

Lopes, F.C.F. 2002. Taxa de passagem, digestibilidade in situ, consumo, composição química e disponibilidade de capim-elefante (Pennisetum purpureum, Schumack) pastejo por vacas mestiças Holandês $\times$ Zebu em lactação. 223 p. (D.Sc. Thesis) - Federal University of Minas Gerais, Belo Horizonte, Brazil.

Marichal, M.J., Trujillo, A.I., Cadenazzi, M., Arias, G. 2011. Fiber analysis: Evaluation of screen printing fabric filters bags by three statistical approaches. Animal Feed Science and Technology 169: 79-85.

Mertens, D.R. 2002. Gravimetric determination of amylase-treated neutral detergent fiber in feeds with refluxing in beakers or crucibles: collaborative study. Journal AOAC International 85: 1217-1240.

Möller, J. 2009. Gravimetric Determination of Acid Detergent Fiber and Lignin in Feed: Interlaboratory Study. Journal AOAC International 92: 74-90.

Moreira, J.F.C., Rodriguez, N.M., Fernandes, P.C.C., Veloso, C.M., Saliba, E.O.S., Gonçalves, L. C., Borges, I., Borges, A.L.C.C. 2003. Concentrados protéicos para bovinos: 1. Digestibilidade in situ da matéria seca e da proteína bruta. Arquivo Brasileiro de Medicina Veterinária e Zootecnia 55: 315-323.

Oliveira, R.L., Bagaldo, A.R., Ladeira, M.M. 2008. Desempenho produtivo e custos com alimentação de búfalas lactantes submetidas a dietas com diferentes fontes de lipídeo. Revista Brasileira de Zootecnia 37: 1503-1508.

Santos, R.A., Teixeira. J.C., Pérez, J.R.O. 2003. Estimativa da degradabilidade ruminal de alimentos utilizando a técnica de produção de gás em bovinos, ovinos e caprinos. Ciência e Agrotecnologia 27: 689-695.

Silva, J.S., Queiroz, A.C. 2002. Análise de alimentos: métodos químicos e biológicos. 3.ed. UFV, Viçosa, Brasil. 235 p.

Valadares Filho, S.C., Rocha Júnior, V.R.R., Capelle, E.R. 2001. Tabelas brasileiras de composição de alimentos para bovinos. 1.ed. UFV/ DZO; DPI, Viçosa, Brasil.
Van Soest, P.J. 1963. Use of detergents in the analysis of fibrous feeds. II - a rapid method for determination of fiber and lignin. Journal of the Association of Official Analytical Chemists 46: 829-835.

Van Soest, P.J. 1967. Development of a comprehensive system of feed analysis and its application to forage. Journal Animal Science 26: $119-120$

Van Soest, P.J., Robertson, J.B., Lewis, B.A. 1991. Methods for dietary fiber neutral detergent and no starch polysaccharides in relation to animal nutrition. Journal of Dairy Science 74: 3583-3597.

Zambom, M.A., Santos, G.T., Modesto, E.C., Alcalde, C.R., Gonçalves, G.D., Silva, D. C., Silva, K.T., Faustino, J.O. 2001. Valor nutricional da casca do grão de soja, farelo de soja, milho moído e farelo de trigo para bovinos. Acta Scientiarum. Animal Sciences 23: 937-943. 